\title{
ANALISIS BUTIR SOAL PENILAIAN UJIAN SEMESTER GASAL MATA PELAJARAN IPS DI MTS DARUL MUNA PONOROGO
}

\author{
Muhammad Miftah Khoirul Muharromah ${ }^{1}$, Syafiq Humaisi ${ }^{2}$ \\ ${ }^{1}$ Institut Agama Islam Negeri Ponorogo \\ Khoirul211097@gmail.com \\ ${ }^{2}$ Institut Agama Islam Negeri Ponorogo, \\ syafiqhumaisi@gmail.com
}

\begin{abstract}
Final Semester Assessment requires a quality question item instrument so that it can guarantee the quality of the tests presented to students. To get quality questions, before the questions are used each item needs to be analyzed first. Therefore, it is necessary to analyze the items. The objective to be achieved in the discussion of this thesis is to determine the quality of the items from the Odd Semester Final Assessment in the Social Sciences Subject of MTs Darul Muna Ponorogo. This research is a descriptive quantitative research. In this study, researchers used to measure the quality of the questions by using the validity of the questions, the reliability of the questions, the level of difficulty, the difference power and the distracting function manually by using the Microsoft Excel application. The data collection technique in this study used documentation techniques in the form of questions, question grids, answer keys to questions, and students' answers. Based on the results of the item analysis in terms of validity, reliability, level of difficulty, distinguishing power, and deception function, it can be concluded that the quality of the Odd End Semester Assessment (PAS) items in the Social Sciences subject MTs Darul Muna Ponorogo in the 2019/2020 school year is a problem good enough quality. because those who meet the criteria for good (very good, good, moderate) questions in class VII are 38 out of 50 items (76\%), in class VIII there are 44 out of 50 items (88\%), class IX totals 35 of 50 items questions (70\%)
\end{abstract}

Keywords: Question Item Analysis; Final Semester Assessment; Social Sciences

\begin{abstract}
ABSTRAK
Penilaian Ujian Akhir membutuhkan instrumen soal yang berkualitas sehingga dapat menjamin kualitas tes yang disajikan kepada siswa. Untuk mendapatkan soal yang berkualitas, sebelum soal digunakan tiap soal perlu dianalisis terlebih dahulu. Oleh karena itu perlu dilakukan analisis terhadap item-item tersebut. Tujuan yang ingin dicapai dalam pembahasan skripsi ini adalah untuk mengetahui kualitas materi dari Penilaian Akhir Semester Ganjil Mata Pelajaran Ilmu Sosial MTs Darul Muna Ponorogo. Penelitian ini merupakan penelitian kuantitatif deskriptif. Dalam penelitian ini peneliti mengukur kualitas soal dengan menggunakan validitas soal, reliabilitas soal, tingkat kesulitan, perbedaan daya dan fungsi distraksi secara manual dengan menggunakan aplikasi Microsoft Excel. Teknik pengumpulan data dalam penelitian ini menggunakan teknik dokumentasi berupa soal, kisi soal, kunci jawaban soal, dan jawaban siswa. Berdasarkan hasil analisis butir soal validitas, reliabilitas, tingkat kesukaran, daya pembeda, dan fungsi penipuan, dapat disimpulkan bahwa kualitas butir soal Penilaian Akhir Semester Ganjil (PAS) mata pelajaran IPS MTs Darul. Muna Ponorogo pada tahun ajaran 2019/2020 merupakan masalah kualitas yang cukup baik. karena yang memenuhi kriteria baik (sangat baik, baik, sedang) soal di kelas VII sebanyak 38 dari 50 item (76\%), di kelas VIII ada 44 dari 50 item (88\%), kelas IX berjumlah 35 dari 50 item pertanyaan (70\%)
\end{abstract}

Kata Kunci: Analisis Butir Soal; Penilaian Akhir Semester; Ilmu Pengetauan Sosial

Copyright (c) 2020 Muhammad Miftah Muharromah, Syafiq Humaisi 
Analisis Butir Soal Penilaian Akhir Semester Gasal Mata Pelajaran Ilmu Pengetahuan Sosial MTs

Darul Muna Ponorogo Tahun Pelajaran 2019/2020

\section{PENDAHULUAN}

Tercapainya target atau tujuan pendidikan, perlu didukung dengan evaluasi pada pembelajaran sebagai tolok ukur untuk mengetahui sampai seberapa jauh tingkat kompetensi yang dicapai pembelajar dari materi yang sudah dipelajari. Evaluasi yang dilaksanakan pada peserta didik juga berbagai macam jenisnya. Jika dilihat dari waktu pelaksanaannya, terdapat evaluasi yang dilaksanakan tiap pertemuan selesai untuk mengukur hasil belajar atau yang biasa disebut refleksi, ada juga evaluasi yang biasa dilaksanakan tiap selesainya satu kompetensi dasar (KD) yaitu ulangan harian (UH) terdapat juga evaluasi yang dilaksanakan tiap pertengahan semester atau yang dulu sering disebut ujian tengah semester (UTS) dan sekarang berganti menjadi penilaian tengah semester (PTS) dan juga terdapat evaluasi yang dilaksanakan tiap akhir semester yangdahulu biasa disebut ujian akhir semester (UAS) sekarang berganti menjadi penilaian akhir semester (PAS). Dari serangkaian evaluasi yang harus dilaksanakan oleh peserta didik tentunya soal yang diberikan kepada peserta didik harus memiliki kualitas yang baik karena harus menjadi tolak ukur penilaian dari peserta didik secara tepat.

Mengingat pentingnya intrumen dalam kaitan ini adalah soal-soal tes tersebut dalam proses penilaian capaian peserta didik, maka dalam melaksanakan Penilaian Akhir Semester dibutuhkan instrumen butir soal yang berkualitas sehingga dapat menjamin kualitas tes yang disajikan kepada peserta didik. Untuk mendapatkan soal yang bermutu maka sebelum soal digunakan setiap butir soal perlu dianalisis terlebih dahulu. Hal ini bertujuan untuk membantu meningkatkan tes melalui revisi atau membuang soal yang tidak efektif, serta untuk mengetahui informasi apakah peserta didik telah menguasai materi yang diajarkan oleh guru.

Kegiatan menganalisis butir soal merupakan suatu kegiatan yang harus dilakukan guru untuk meningkatkan mutu soal yang telah ditulis. Kegiatan ini merupakan proses pengumpulan, peringkasan, dan penggunaan informasi dari jawaban siswa untuk membuat keputusan tentang setiap penilaian. Analisis butir soal ini berisi uji validitas, uji reliabilitas, tingkat kesukaran, daya pembeda dan fungsi pengecoh atau distractor soal. Tujuan penelaahan adalah untuk mengkaji dan menelaah setiap butir soal agar diperoleh soal yang bermutu sebelum soal digunakan. Di samping itu, tujuan analisis butir soal juga untuk membantu meningkatkan tes melalui revisi atau membuang soal yang tidak efektif, serta untuk mengetahui informasi diagnostik pada siswa apakah mereka sudah atau belum memahami materi yang telah diajarkan. ${ }^{1}$

Jika kualitas setiap butir soal belum diketahui secara pasti, maka akan berpengaruh pada kecenderungan kesalahan pada penafsiran hasil tes. Hal ini tentunya berdampak pada biasnya informasi yang diperoleh dari alat penilaian mengenai kemampuan peserta didik yang sebenarnya. Oleh karena itu, haruslah diadakan pengembangan dalam pembuatan tes pilihan ganda pada Penilaian Akhir Semester hasil dari Musyawarah Guru Mata Pelajaran secara terstruktur dan terencana agar dapat memperoleh hasil evaluasi yang objektif dan akurat khususnya harus ada analisis pada kualitas butir soal. Beranjak dari permasalahan

${ }^{1}$ Depdiknas, Panduan Analisis Butir Soal (Jakarta: Dirjen Menajemen Pendidikan Dasar dan Menengah, 2008), 166.

103 ASANKA: Journal Of Social Sciencs and Education, 1 (2), 2020. 
Analisis Butir Soal Penilaian Akhir Semester Gasal Mata Pelajaran Ilmu Pengetahuan Sosial MTs Darul Muna Ponorogo Tahun Pelajaran 2019/2020

yang terjadi di MTs Darul Muna Ponorogo tersebut, peneliti pada penelitian ini akan melakukan telaah dan uji kualitas butir soal dari tes pilihan ganda yang telah dibuat dalam Musyawarah Guru Mata Pelajaran Ilmu Pengetahuan Sosial tersebut, dengan judul penelitian Analisis Butir Soal Penilaian Akhir Semester Gasal Mata Pelajaran Ilmu Pengetahuan Sosial MTs darul Muna Ponorogo Tahun Ajaran 2019/2020.

\section{METODE PENELITIAN}

Metode penelitian meliputi data dan teknik pengumpulan data, model penelitian, definisi operasional variabel dan metode analisis data. Boleh menggunakan penomoran bertingkat (bila perlu). Jangan lupa memberikan judul dan nomor gambar (di bawah gambar dan nomor terurut) serta judul dan nomor tabel (di atas tabel dengan nomor terurut).

Penelitian ini menggunakan metode penelitian deskriptif dengan pendekatan kuantitatif yang mana data yang dibutuhkan adalah nama siswa, Kisi-kisi, Kunci jawaban, Lembar hasil kerja Ujian Semester Gasal Mata Pelajaran Ilmu Pengetahuan Sosial siswa kelas VII, VIII dan IX MTs Darul Muna Ponorogo. Menurut Suharsimi Instrumen penelitian merupakan alat atau fasilitas yang digunakan oleh peneliti dalam mengumpulkan data agar pekerjaannya lebih mudah dah hasilnya lebih baik, dalam arti lebih cermat, lengkap dan sistematis sehingga mudah diolah. ${ }^{2}$ Karena penelitian ini membahas terkait analisis butir soal Penilaian Akhir Semester Gasal, maka didalam penelitian ini peneliti menggunakan data sekunder dengan teknik pengumpulan data berupa dokumentasi.

Penelitian ini merupakan penelitian deskriptif. Penelitian deskriptif merupakan metode penelitian yang berusaha menggambarkan dan menginterpretasikan objek sesuai dengan apa adanya. Penelitian ini mendeskripsikan atau menggambarkan suatu kejadian yang terjadi secara faktual, sistematis dan akurat. Penelitian ini menggambarkan data kuantitatif yang diperoleh menyangkut keadaan subjek atau respons dari suatu populasi, maka pendekatan yang digunakan adalah pendekatan kuantitatif. ${ }^{3}$ Dengan pendekatan tersebut ditujukan untuk menganalisis butir soal Penilaian Akhir Semester Gasal di MTs Darul Muna Ponorogo, karena itu teknik analisis data yang dilaksanakan adalah sebagai berikut:

\section{Validitas}

Menurut Suharsimi, validitas adalah suatu ukuran yang menujukkan tingkattingkat kevalidan atau kesahihan suatu instrumen. Suatu instrumen dikatakan valid apabila mampu mengukur apa yang hendak diukur. ${ }^{4}$ Uji validitas disini dimaksudkan untuk menguji masing-masing butir soal pada Penilaian Akhir Semester. Untuk menghitung validitas dapat menggunakan rumus korelasi product moment dengan rumus sebagai berikut:

${ }^{2}$ Suharsimi Arikunto, Dasar-dasar Evaluasi Pendidikan. (Jakarta: Bumi Aksara, 2013), 136.

${ }^{3}$ Nuril Hudaa dan Tutik Sri Wahyuni, "Analisis Butir Soal IPA Try Out USBN Tahun Ajaran 2018/2019 dalam Kaitannya dengan Level Kognitif," Jurnal Pendidikan dan Pembelajaran Dasar Madrasah, 01 (Desember 2019), 32.

${ }^{4}$ Aditya Melia Nugrahanti, "Analisis Butir Soal Ujian Akhir Semester Gasal Mata Pelajaran Akuntansi Keuangan Kelas XI Kompetensi Keahlian Akuntansi SMK Negeri 1 Yogyakarta tahun ajaran 2012/2013," (Skripsi, FE UNY, Yogyakarta, 2013) 
Analisis Butir Soal Penilaian Akhir Semester Gasal Mata Pelajaran Ilmu Pengetahuan Sosial MTs Darul Muna Ponorogo Tahun Pelajaran 2019/2020

$$
r_{x y}=\frac{N \cdot \sum x y-\left(\sum x\right)\left(\sum y\right)}{\sqrt{\left(N \cdot \sum x^{2}-\left(\sum x\right)^{2}\right) \cdot\left(N \cdot \sum y^{2}-\left(\sum y\right)^{2}\right)}}
$$

\section{Reliabilitas}

Reliabilitas digunakan untuk menguji keajegan pertanyaan tes bila diberikan berulangkali pada objek yang sama. Tes dikatakan reliabel atau ajeg bila dalam beberapa kali tes tersebut diujikan memberikan hasil yang relatif sama. Uji reliabilitas pada penelitian ini menggunakan rumus Spearman Born yaitu:

$r_{i}=\frac{2 r_{b}}{1+r_{h}}$

\section{Dimana:}

$\mathrm{r}_{\mathrm{i}}=$ Reliabilitas internal seluruh instrumen

$\mathrm{r}_{\mathrm{b}}=$ Korelasi Product Moment antara belahan pertama dan kedua,

\section{Daya Pembeda}

Soal yang baik adalah soal yang sedang, tidak terlalu mudah dan tidak terlalu sukar. Bilangan yang menunjukkan sukar dan mudahnya suatu soal disebut indeks kesukaran (difficulty indexs). Besarnya indeks kesukaran antara 0,00 sampai 1,00. Indeks kesukaran ini menunjukkan tingkat kesukaran soal. Soal dengan indeks kesukaran 0,00 menunjukkan bahwa soal itu terlalu sukar, sebaliknya indeks 1,00 menunjukkan bahwa soal terlalu mudah. Untuk tes bentuk objektif dalam menghitung tingkat kesukaran dapat dilakukan dengan menggunakan rumus sebagai berikut:

$P=\frac{B}{J S}$

Keterangan:

$\mathrm{P}=$ angka indeks kesukaran item

$\mathrm{B}=$ banyak siswa yang menjawab betul

JS = Jumlah siswa peserta tes

Kriteria kesukaran:

$0,71-1,00:$ Mudah

$0,31-0,70:$ Sedang

$0,00-0,30:$ Sulit

\section{Tingkat Kesukaran}

Daya pembeda soal adalah kemampuan suatu butir soal untuk membedakan antara siswa yang telah menguasai materi dan siswa yang belum menguasai materi yang ditanyakan. Angka yang menunjukkan besarnya daya pembeda disebut indeks daya pembeda (DP). Semakin tinggi indeks daya pembeda soal berarti semakin mampu soal yang bersangkutan membedakan siswa yang sudah memahami dan belum memahami materi. Indeks daya pembeda berkisar antara $-1,00$ sampai dengan $+1,00$. Semakin tinggi daya pembeda suatu soal maka semakin baik soal tersebut. Jika daya pembeda negatif berarti lebih banyak kelompok siswa yang belum memahami materi menjawab benar soal tersebut. Dapat dihitung dengan menggunakan rumus:

$D=\frac{B_{A}}{J_{A}}-\frac{B_{B}}{J_{R}}=P_{A}-P_{B}$

Keterangan:

$\mathrm{D}=$ angka indeks diskriminasi 
Analisis Butir Soal Penilaian Akhir Semester Gasal Mata Pelajaran Ilmu Pengetahuan Sosial MTs

Darul Muna Ponorogo Tahun Pelajaran 2019/2020

$\mathrm{JA}=$ banyaknya peserta kelompok atas

$\mathrm{JB}=$ banyaknya peserta keompok bawah

$\mathrm{BA}=$ banyaknya peserta kelompok atas yang menjawab dengan benar

$\mathrm{BB}=$ banyaknya peserta kelompok bawah yang menjawab dengan benar

$\mathrm{PA}=$ proporsi peserta kelompok atas menjawab benar

$\mathrm{PB}=$ proporsi peserta kelompok bawah menjawab benar Perhitungan indeks daya pembeda dapat disimpulkan dengan acuan sebagai berikut:

D : $0,00-0,20:$ jelek (poor)

D : $0,21-0,40$ : cukup (satisfactory)

D : $0,41-0,70$ : baik (good)

D : $0,71-1,00$ : baik sekali (excellent)

D : negatif, semuanya tidak baik. Jadi semua butir soal yang mempunyai nilai

D negatif sebaiknya dibuang saja. ${ }^{5}$

\section{Fungsi Pengecoh/ Distractor}

Kunci jawaban dan pengecoh pada suatu soal perlu diketahui berfungsi tidaknya kunci jawaban atau pengecoh tersebut. Tujuan utama dari pemasangan distraktor atau pengecoh pada setiap butir soal adalah agar para siswa yang mengikuti ujian akhir semester tertarik untuk memilih jawaban yang salah, karena mereka mengira bahwa distraktor yang mereka pilih itu merupakan jawaban benar. Jika siswa banyak yang memilih distraktor tersebut sebagai jawaban, berarti distraktor tersebut berfungsi dengan baik. Namun sebaliknya, jika sedikit siswa yang terkecoh dengan distraktor, maka semakin kurang distraktor tersebut berfungsi. ${ }^{6}$ Efektivitas pengecoh dapat diukur menggunakan rumus:

$$
I P=\frac{P}{(N-B) /(n-1)} \times 100 \%
$$

Keterangan:

IP $=$ indeks pengecoh.

$\mathrm{P}=$ jumlah peserta didik yang memilih pengecoh.

$\mathrm{N}=$ jumlah peserta didik yang ikut tes.

$\mathrm{B}=$ jumlah peserta didik yang menjawab benar.

$\mathrm{n}=$ jumlah alternatif jawaban.

$1=$ bilangan tetap

Anas Sudijono mengungkapkan bahwa distractor telah dapat menjalankan fungsinya dengan baik apabila distractor tersebut telah dipilih sekurangkurangnya $5 \%$ dari seluruh peserta tes. ${ }^{7}$

\section{HASIL DAN PEMBAHASAN}

Kegiatan menganalisis butir soal merupakan suatu kegiatan yang harus dilakukan guru untuk meningkatkan mutu soal yang telah ditulis. Kegiatan ini merupakan proses pengumpulan, peringkasan, dan penggunaan informasi dari jawaban siswa untuk membuat keputusan tentang setiap penilaian. Tujuan

\footnotetext{
${ }^{5}$ Suharsimi Arikunto, Dasar-dasar Evaluasi Pendidikan, 232.

${ }^{6}$ Putu Ngurah Rusmawan, "Analisis Butir Soal Ujian Akhir Semester Mata Pelajaran Bahasa Inggris Kelas VII SMPN 2 Tegalsiwalan,” Jurnal Linguista, 01, 2018), 40.

7 Ata Nayla Amalia dan Ani Widayati, "Analisis Butir Soal Tes Kendali Mutu Kelas XII SMA Mata Pelajaran Ekonomi Akuntansi Di Kota Yogyakarta Tahun 2012," Jurnal Pendidikan Akuntansi Indonesia, 1, 2012), 13.
} 
Analisis Butir Soal Penilaian Akhir Semester Gasal Mata Pelajaran Ilmu Pengetahuan Sosial MTs Darul Muna Ponorogo Tahun Pelajaran 2019/2020

penelaahan adalah untuk mengkaji dan menelaah setiap butir soal agar diperoleh soal yang bermutu sebelum soal digunakan. Di samping itu, tujuan analisis butir soal juga untuk membantu meningkatkan tes melalui revisi atau membuang soal yang tidak efektif, serta untuk mengetahui informasi diagnostik pada siswa apakah mereka sudah atau belum memahami materi yang telah diajarkan. ${ }^{8}$

Kualitas butir soal dapat dianalisis berdasarkan beberapa ketentuan yaitu validitas, reliabilitas, tingkat kesukaran, daya beda dan efektifitas pengecoh (distractor). Berdasarkan Hasil analisis validitas, reliabilitas, daya pembeda, tingkat kesukaran, dan efektivitas pengecoh butir soal kemudian dianalisis secara bersama-sama untuk mengetahui kualitas butir soal. Kemudian dari hasil analisis terhadap ketentuan tersebut kualitas butir soal diketahui berdasarkan kriteria yang diadaptasi dari Skala Likert sebagai berikut: $^{9}$

1. Butir soal dikatakan sangat baik apabila memenuhi 4 kriteria soal yang baik yaitu Validitas, Tingkat Kesukaran, Daya Pembeda, dan Efektivitas Pengecoh. Pada kondisi ini butir soal bisa masuk ke bank soal.

2. Butir soal dikatakan baik jika memenuhi 3 kriteria dari 4 kriteria soal yang baik (Validitas, Tingkat Kesukaran, Daya Pembeda, dan Efektivitas Pengecoh). Pada kondisi ini butir soal belum bisa masuk ke bank soal. Soal harus direvisi hingga memenuhi empat kriteria.

3. Butir soal dikatakan sedang jika memenuhi 2 kriteria dari 4 kriteria soal yang baik (Validitas, Tingkat Kesukaran, Daya Pembeda, dan Efektivitas Pengecoh). Pada kondisi ini butir soal belum bisa masuk ke bank soal. Soal harus direvisi hingga memenuhi empat kriteria.

4. Butir soal dikatakan tidak baik jika memenuhi 1 dari 4 kriteria sebagai soal yang baik (Validitas, Tingkat Kesukaran, Daya Pembeda, dan Efektivitas Pengecoh). Pada kondisi ini butir soal tidak bisa masuk ke bank soal. Soal membutuhkan revisi signifikan sehingga lebih baik dibuang.

5. Butir soal dikatakan sangat tidak baik jika tidak memenuhi seluruh kriteria sebagai soal yang baik (Validitas, Tingkat Kesukaran, Daya Pembeda, dan Efektivitas Pengecoh). Pada kondisi ini butir soal tidak bisa masuk ke bank soal. Soal membutuhkan revisi signifikan sehingga lebih baik dibuang.

6. Selain syarat berbasis butir, maka tes secara keseluruhan harus reliabel dengan ketentuan sebagaimana yang sudah dijelaskan diatas.

Berdasarkan hasil analisis sesuai dengan kriteria yang sudah ditentukan terhadap Soal Penilaian Akhir Semester Gasal Mata Pelajaran Ilmu Pengetahuan Sosial kelas VII MTs Darul Muna Ponorogo Tahun Ajaran 2019/2020 diatas soal yang berpredikat sangat baik terdapat 13 soal atau $26 \%$ dari jumlah keseluruhan soal, soal yang berpredikat baik terdapat 13 soal atau $26 \%$ dari jumlah keseluruhan soal, soal yang berpredikat sedang terdapat 12 soal atau $24 \%$ dari jumlah keseluruhan soal, soal yang berpredikat tidak baik terdapat 9 soal atau $18 \%$ dari jumlah keseluruhan soal, soal yang berpredikat sangat tidak baik terdapat 3 soal atau 9\% dari jumlah keseluruhan soal. Berikut kami tampilkan penjabarannya.

${ }^{8}$ Depdiknas, Panduan Analisis Butir Soal (Jakarta: Dirjen Menajemen Pendidikan Dasar dan Menengah, 2008), 166.

${ }^{9}$ Wika Sevi Oktanin, Analisis Butir Soal Ujian Akhir Semester Genap Mata Pelajaran Ekonomi Akuntansi Kelas XI IPS SMA N 1 Kalasan Tahun Ajaran 2013/2014 (Yogyakarta: Skripsi Jurusan Pendidikan Akuntansi, Fakultas Ekonomi, Universitas Negeri Yogyakarta, 2015), 7.

107 ASANKA: Journal Of Social Sciencs and Education, 1 (2), 2020. 
Analisis Butir Soal Penilaian Akhir Semester Gasal Mata Pelajaran Ilmu Pengetahuan Sosial MTs

Darul Muna Ponorogo Tahun Pelajaran 2019/2020

Tabel 1. Hasil Analisis Kualitas Butir Soal Penilaian Akhir Semester (PAS) Gasal Mata Pelajaran Ilmu Pengetahuan Sosial Kelas VII MTs Darul Muna Ponorogo Tahun Pelajaran 2019/2020

\begin{tabular}{|c|c|c|c|c|}
\hline No & Fungsi Pengecoh & Butir Soal & Jumlah & Persentase \\
\hline & Sangat Baik & $\begin{array}{l}2,3,7,11,16,18,21, \\
24,25,31,40,42,47\end{array}$ & & $26 \%$ \\
\hline & Baik & $\begin{array}{l}4,5,8,9,26,29,32, \\
33,35,38,44,49,50\end{array}$ & & $26 \%$ \\
\hline & Sedang & $\begin{array}{l}1,14,15,20,22,34, \\
36,41,43,45,46,48\end{array}$ & 12 & $24 \%$ \\
\hline & Tidak Baik & $\begin{array}{l}6,12,13,17,19,23, \\
27,37,39\end{array}$ & 9 & $18 \%$ \\
\hline & $\begin{array}{l}\text { Sangat } \quad \text { Tidak } \\
\text { Baik }\end{array}$ & $10,28,30$ & 3 & $9 \%$ \\
\hline
\end{tabular}

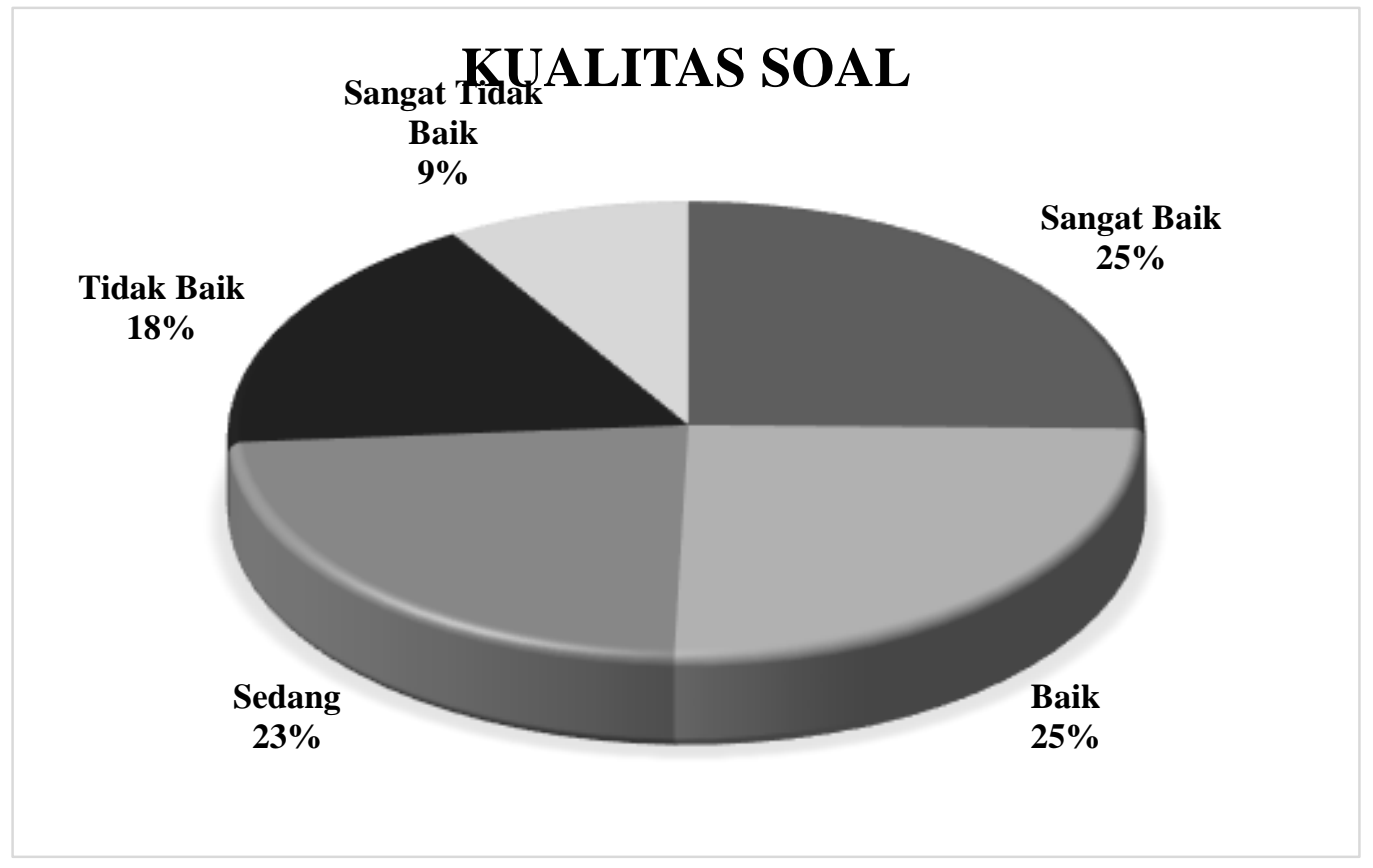

Sedangkan untuk soal Penilaian Akhir Semester Mata Pelajaran Ilmu Pengetahuan Sosial kelas VIII MTs Darul Muna Ponorogo Tahun Ajaran 2019/2020 Berdasarkan hasil analisis sesuai dengan kriteria yang sudah ditentukan diatas soal yang berpredikat sangat baik terdapat 7 soal atau $14 \%$ dari jumlah keseluruhan soal, soal yang berpredikat baik terdapat 23 soal atau $46 \%$ dari jumlah keseluruhan soal, soal yang berpredikat sedang terdapat 14 soal atau $28 \%$ dari jumlah keseluruhan soal, soal yang berpredikat tidak baik terdapat 5 soal atau $10 \%$ dari jumlah keseluruhan soal, soal yang berpredikat sangat tidak baik terdapat 1 soal atau $2 \%$ dari jumlah keseluruhan soal. Berikut kami tampilkan penjabarannya. 
Analisis Butir Soal Penilaian Akhir Semester Gasal Mata Pelajaran Ilmu Pengetahuan Sosial MTs Darul Muna Ponorogo Tahun Pelajaran 2019/2020

Tabel 2. Hasil Analisis Kualitas Butir Soal Penilaian Akhir Semester (PAS) Gasal Mata Pelajaran Ilmu Pengetahuan Sosial Kelas VIII MTs Darul Muna Ponorogo Tahun Pelajaran 2019/2020

\begin{tabular}{|c|c|c|c|c|}
\hline No. & Fungsi Pengecoh & Butir Soal & Jumlah & Persentase \\
\hline 1 & Sangat Baik & $\begin{array}{l}24,26,30,41,42,47, \\
49\end{array}$ & 7 & $14 \%$ \\
\hline 2 & Baik & $\begin{array}{l}1,5,8,10,11,12,13, \\
16,17,18,20,21,23, \\
25,27,31,35,36,37, \\
40,43,48,50\end{array}$ & 23 & $26 \%$ \\
\hline 3 & Sedang & $\begin{array}{l}2,3,4,6,15,28,32, \\
33,34,38,39,44,45, \\
46\end{array}$ & 14 & $28 \%$ \\
\hline 4 & Tidak Baik & $9,14,19,22,29$ & 5 & $10 \%$ \\
\hline 5 & $\begin{array}{ll}\text { Sangat } & \text { Tidak } \\
\text { Baik } & \end{array}$ & 7 & 1 & $2 \%$ \\
\hline
\end{tabular}

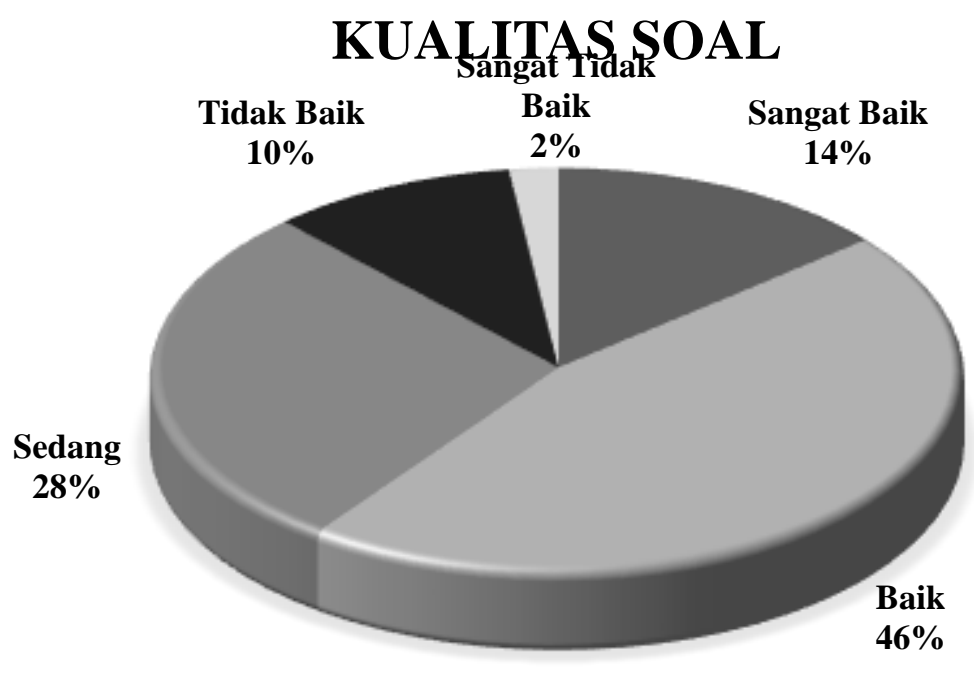

Hasil analisis soal Penilaian Akhir Semester Mata Pelajaran Ilmu Pengetahuan Sosial kelas IX MTs Darul Muna Ponorogo Tahun Ajaran 2019/2020 Berdasarkan hasil analisis sesuai dengan kriteria yang sudah ditentukan diatas soal yang berpredikat sangat baik terdapat 8 soal atau $16 \%$ dari jumlah keseluruhan soal, soal yang berpredikat baik terdapat 14 soal atau $28 \%$ dari jumlah keseluruhan soal, soal yang berpredikat sedang terdapat 13 soal atau $26 \%$ dari jumlah keseluruhan soal, soal yang berpredikat tidak baik terdapat 13 soal atau $26 \%$ dari jumlah keseluruhan soal, soal yang berpredikat sangat tidak baik terdapat 2 soal atau $4 \%$ dari jumlah keseluruhan soal. Berikut kami tampilkan penjabarannya.

Tabel 3 Hasil Analisis Kualitas Butir Soal Penilaian Akhir Semester (PAS) Gasal Mata Pelajaran Ilmu Pengetahuan Sosial Kelas IX MTs Darul Muna Ponorogo Tahun Pelajaran 2019/2020

\begin{tabular}{llllll}
\hline No. & Fungsi Pengecoh & Butir Soal & Jumlah & Persentase \\
\hline 1 & Sangat Baik & $1,2,30,36,40,41$, & 8 & $16 \%$ \\
\hline
\end{tabular}


Analisis Butir Soal Penilaian Akhir Semester Gasal Mata Pelajaran Ilmu Pengetahuan Sosial MTs Darul Muna Ponorogo Tahun Pelajaran 2019/2020

\begin{tabular}{|c|c|c|c|}
\hline & & 45,49 & \\
\hline 2 & Baik & $\begin{array}{l}6,9,11,13,15,22,14 \\
26,27,29,31,38,43, \\
44,47\end{array}$ & $\%$ \\
\hline 3 & Sedang & $\begin{array}{l}3,4,5,12,16,20,25,13 \\
28,33,35,42,46,48\end{array}$ & $26 \%$ \\
\hline 4 & Tidak Baik & $\begin{array}{l}7,10,14,17,18,19,13 \\
21,23,24,32,34,37, \\
50\end{array}$ & $26 \%$ \\
\hline 5 & $\begin{array}{l}\text { Sangat } \\
\text { Baik }\end{array}$ & 8,39 & $4 \%$ \\
\hline
\end{tabular}

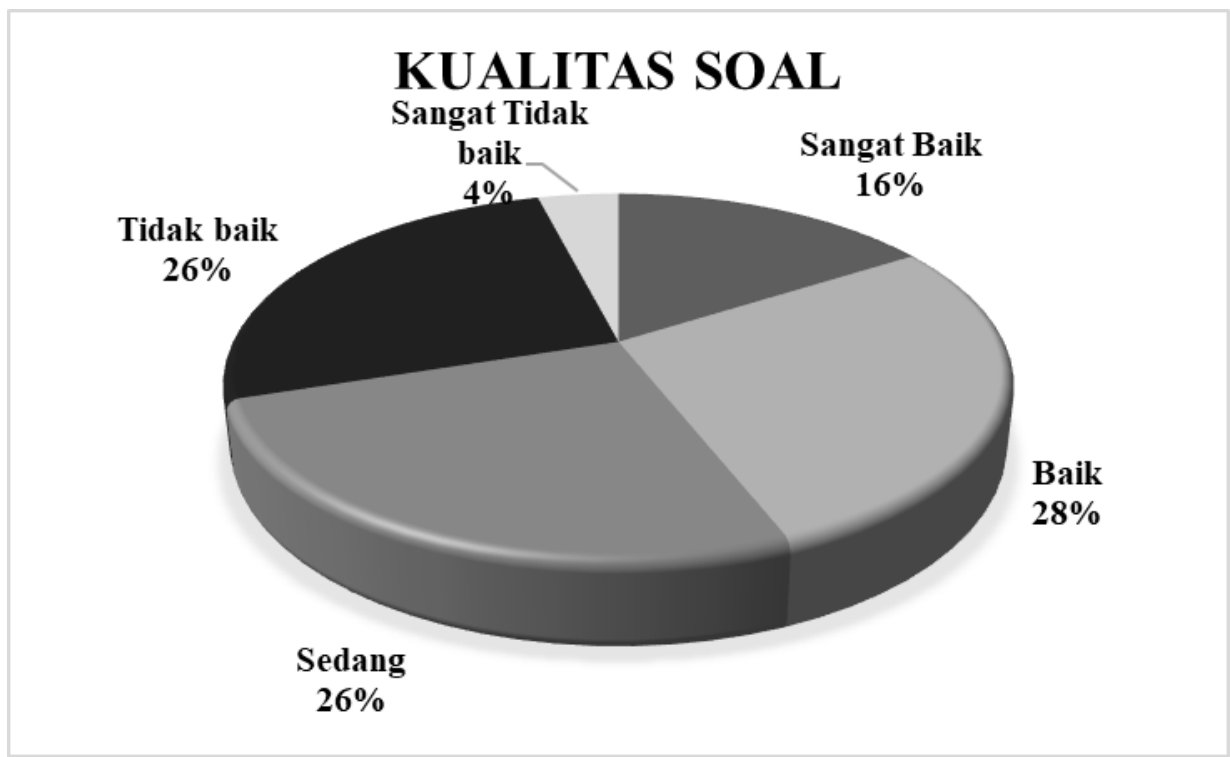

Dari hasil tersebut jika diperbandingkan dengan hasil penelitian yang pernah dilakukan oleh Shinta Widyarini yang berjudul "Analisis Butir Soal Ujian Semester Gasal Mata Pelajaran Ekonomi Akutansi Kelas XII IPS SMA N 1 Kalasan tahun 2014/2015 yang hasil analisisnya menunjukkan soal yang berkualitas sangat baik berjumlah 3 butir soal atau $6 \%$, soal yang berkualitas baik berjumlah 11 butir atau 22\%, soal yang berkualitas sedang berjumlah 7 butir atau $14 \%$, soal yang berjumlah tidak baik berjumlah 16 butir atau $32 \%$, dan soal yang berkualitas sangat tidak baik berjumlah 13 butir atau 26\%. Hasil analisis menunjukkan 7 butir soal memerlukan revisi dan 29 soal sebaiknya dibuang. ${ }^{10} \mathrm{Hal}$ tersebut menunjukkan butir soal belum menjalankan fungsinya dengan baik. Maka soal Penilaian Akhir Semester (PAS) Gasal Mata Pelajaran Ilmu Pengetahuan Sosial MTs Darul Muna Ponorogo Tahun Pelajaran 2019/2020 sudah lebih baik dibandingkan Soal Ujian Semester Gasal Mata Pelajaran Ekonomi Akutansi Kelas XII IPS SMA N 1 Kalasan tahun 2014/2015.

Butir soal yang kualitasnya sangat baik bisa langsung dimasukkan ke bank soal dengan tetap menjaga kerahasiaan soal tersebut sehingga dapat digunakan lagi untuk ujian yang akan datang. Butir soal yang kualitasnya baik dan sedang belum bisa dimasukkan ke dalam bank soal karena harus dilakukan revisi ringan

10 Shinta Widyarini, Analisis Kualitas Butir Soal Ujian Akhir Semester Gasal Mata Pelajaran Ekonomi Akuntansi Kelas Xii IPS SMA N 1 Kalasan Tahun 2014/2015 (Yogyakarta: Skripsi Program Studi Pendidikan Akuntansi, Jurusan Pendidikan Akuntansi, Fakultas Ekonomi, Universitas Negeri Yogyakarta, 2015), 7. 
Analisis Butir Soal Penilaian Akhir Semester Gasal Mata Pelajaran Ilmu Pengetahuan Sosial MTs Darul Muna Ponorogo Tahun Pelajaran 2019/2020

dan sedang terlebih dahulu sesuai dengan indikator kegagalannya. Butir soal yang kualitasnya tidak baik dan sangat tidak baik lebih baik dibuang karena butir tersebut membutuhkan revisi yang signifikan.

Hasil analisis menunjukkan soal Penilaian Akhir Semester (PAS) Gasal Mata Pelajaran Ilmu Pengetahuan Sosial MTs Darul Muna Ponorogo Tahun Pelajaran 2019/2020

1. kelas VII sebanyak 13 soal dapat langsung masuk bank soal, 25 butir soal memerlukan revisi dan 11 butir soal yang lebih baik dibuang,

2. kelas VIII sebanyak 7 soal dapat langsung masuk bank soal, 37 butir soal memerlukan revisi dan 6 butir soal yang lebih baik dibuang,

3. kelas VIII sebanyak 8 soal dapat langsung masuk bank soal, 27 butir soal memerlukan revisi dan 15 butir soal yang lebih baik dibuang,

Hal tersebut menunjukkan bahwa butir soal belum bisa menjalankan fungsinya dengan baik. Penyebab kegagalan butir soal tersebut dapat ditelusuri dari aspek validitas, daya pembeda, tingkat kesukaran, dan efektivitas pengecoh tiap butir soal. Penyebab kegagalan butir soal tersebut dijabarkan pada tabel berikut ini.

Tabel 4. Penyebab Kegagalan Butir Soal

\begin{tabular}{|c|c|c|c|c|c|c|c|}
\hline \multirow{2}{*}{ No } & \multirow[b]{2}{*}{ Penyebab } & \multicolumn{2}{|c|}{ Kelas VII } & \multicolumn{2}{|c|}{ Kelas VIII } & \multicolumn{2}{|c|}{ Kelas IX } \\
\hline & & Jumlah & Pesertase & Jumlah & Pesertase & Jumlah & $\begin{array}{l}\text { Pesen } \\
\text { tase }\end{array}$ \\
\hline 1 & $\begin{array}{l}\text { Validitas (tidak } \\
\text { valid) }\end{array}$ & 30 & $60 \%$ & 36 & $72 \%$ & 40 & $80 \%$ \\
\hline 2 & $\begin{array}{l}\text { Tingkat } \\
\text { Kesukaran } \\
\text { (sukar dan } \\
\text { Mudah) }\end{array}$ & 16 & $32 \%$ & 17 & $34 \%$ & 25 & $50 \%$ \\
\hline 3 & $\begin{array}{l}\text { Daya Pembeda } \\
\text { (tidak baik dan } \\
\text { negatif) }\end{array}$ & 13 & $26 \%$ & 10 & $20 \%$ & 15 & $30 \%$ \\
\hline 4 & $\begin{array}{l}\text { Fungsi } \\
\text { Pengecoh } \\
\text { (kurang baik) }\end{array}$ & 8 & $16 \%$ & 7 & $14 \%$ & 16 & $32 \%$ \\
\hline
\end{tabular}




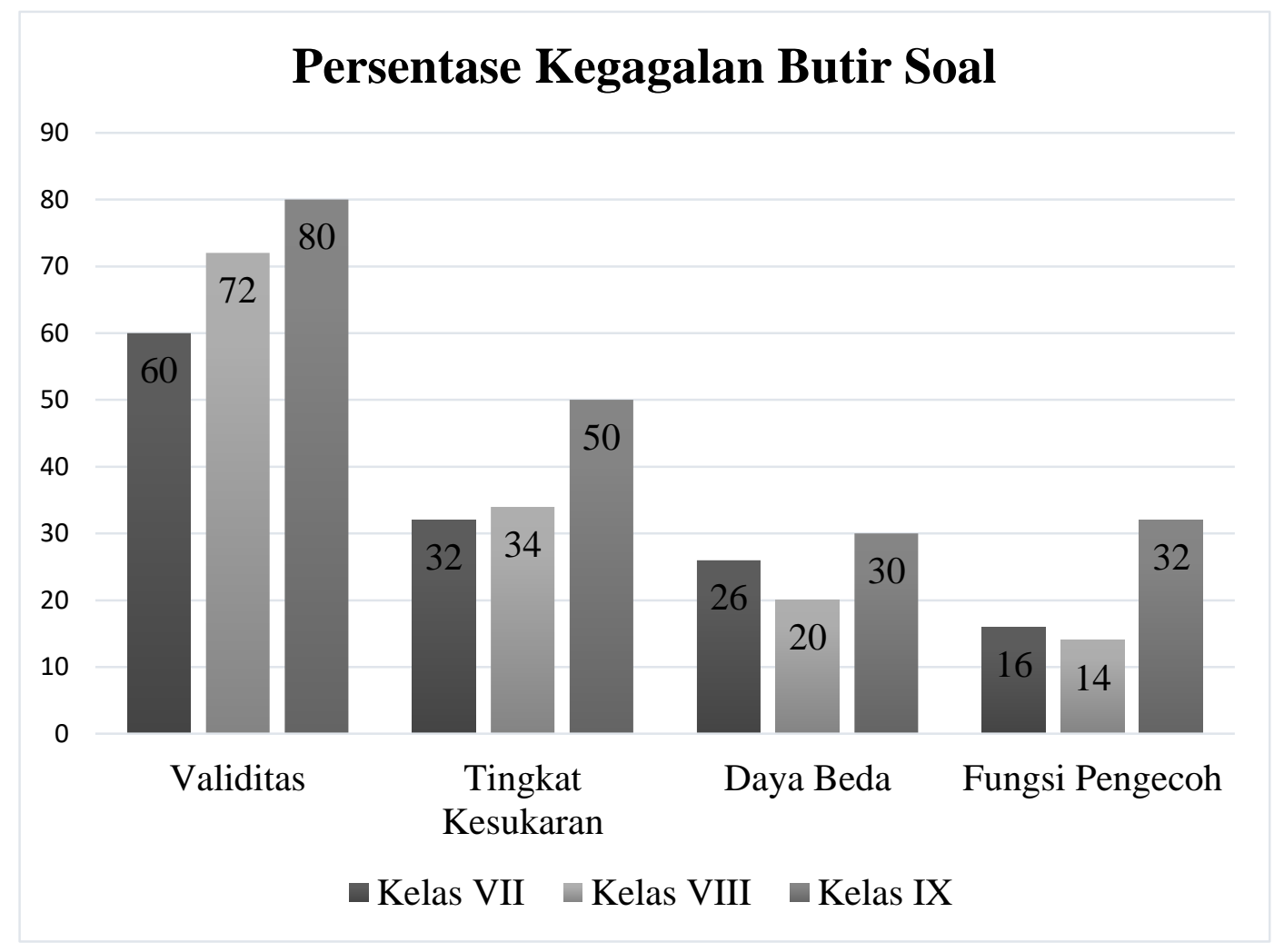

Berdasarkan pada tabel 4. diketahui bahwa penyebab kegagalan butir soal Penilaian Akhir Semester (PAS) Gasal Mata Pelajaran Ilmu Pengetahuan Sosial MTs Darul Muna Ponorogo Tahun Pelajaran 2019/2020 adalah

1. yang pertama adalah validitas soal, hal ini menunjukkan bahwa validitas setiap butir soal belum memiliki dukungan besar terhadap skor total tes.

2. Yang kedua tingkat kesukaran soal, dari segi tingkat kesukaran sebenarnya soal dengan tingkat kesukaran sedang sudah lebih signifikan dari pada soal yang mudah dan soal yang sulit tetapi proporsi ini masih bisa ditingkakan sehingga soal yang terlalu sulit dapat disederhanakan dan soal yang terlalu mudah dapat diperumit..

3. Yang ketiga daya beda soal, sebenarnya soal Penilaian Akhir Semester (PAS) Gasal Mata Pelajaran Ilmu Pengetahuan Sosial sudah cukup mampu untuk membedakan siswa yang pandai dan siswa yang kurang pandai tetapi masih ada sebagian soal yang masih belum mampu untuk membedakan kemampuan siswa.

4. Yang keempat adalah fungsi pengecoh, diketahui bahwa kegagalan pada fungsi pengecoh sebenarnya juga tidak terlalu besar atau mengisyaratkan sebenarnnya jawaban pengecoh soal cukup mampu untuk membuat siswa terkecoh memeilih pengecoh jawaban.

\section{PENUTUP}

Berdasarkan hasil analisis butir soal dari segi validitas, reliabilitas, tingkat kesukaran, daya pembeda, dan fungsi pengecoh dapat disimpulkan bahwa kualitas butir soal Penilaian Akhir Semester (PAS) Gasal mata pelajaran Ilmu Pengetahuan Sosial MTs Darul Muna Ponorogo tahun pelajaran 2019/2020 merupakan soal yang berkualitas cukup baik. karena yang memenuhi kriteria soal yang baik (sangat baik, baik, sedang) pada soal kelas VII berjumlah 38 dari 50 
Analisis Butir Soal Penilaian Akhir Semester Gasal Mata Pelajaran Ilmu Pengetahuan Sosial MTs Darul Muna Ponorogo Tahun Pelajaran 2019/2020

butir (76\%), pada kelas VIII berjumlah 44 dari 50 butir soal (88\%), kelas IX berjumlah 35 dari 50 butir soal (70\%). Hal tersebut berdasarkan pada hasil analisis butir soal sebagai berukut:

1. Validitas dari sebagian kecil butir soal Penilaian Akhir Semester (PAS) Gasal mata pelajaran Ilmu Pengetahuan Sosial MTs Darul Muna Ponorogo tahun pelajaran 2019/2020 menunjukkan valid hal ini berarti kualitas butir soal kurang baik dari segi validitasnya karena pada soal kelas VII hanya terdapat 20 soal yang valid dari 50 soal (40\%), pada kelas VIII hanya terdapat 14 soal yang valid dari 50 soal (28\%) dan pada kelas IX hanya terdapat 10 soal yang valid dari 50 soal $(20 \%)$.

2. Reliabilitas soal Penilaian Akhir Semester (PAS) Gasal mata pelajaran Ilmu Pengetahuan Sosial MTs Darul Muna Ponorogo tahun pelajaran 2019/2020 termasuk pada soal yang berkualitas baik karena angka reliabilitas masingmasing kelas termasuk reliabilitas yang tinggi yaitu nilai $\mathrm{r}_{11}$ kelas VII adalah 0,87146 (reliabilitas tinggi), nilai $\mathrm{r}_{11}$ kelas VIII adalah 0,76038 (reliabilitas tinggi), nilai $\mathbf{r}_{11}$ kelas IX adalah 0, 94247 (reliabilitas tinggi).

3. Tingkat Kesukaran soal Penilaian Akhir Semester (PAS) Gasal mata pelajaran Ilmu Pengetahuan Sosial MTs Darul Muna Ponorogo tahun pelajaran 2019/2020 termasuk pada soal yang berkualitas cukup baik. Karena jumlah soal yang tingkat kesukarannya antara 0,30 - 0,70 (tingkat sedang) adalah separuh lebih dari jumlah keseluruhan soal, yaitu pada soal kelas VII terdapat 34 soal dari 50 soal (68\%), soal kelas VIII terdapat 33 soal dari 50 soal (66\%), soal kelas VII terdapat 25 soal dari 50 soal (50\%).

4. Daya Pembeda soal Penilaian Akhir Semester (PAS) Gasal mata pelajaran Ilmu Pengetahuan Sosial MTs Darul Muna Ponorogo tahun pelajaran 2019/2020 termasuk pada soal yang berkualitas cukup baik. Kerena jumlah soal yang memiliki daya pembeda baik cukup tinggi pada masing-masing kelas yaitu pada soal kelas VII terdapat 37 soal yang baik (Sangat baik, baik dan cukup baik) dari 50 soal (74\%), pada soal kelas VIII terdapat 40 soal yang baik dari 50 soal $(80 \%)$ pada soal kelas IX terdapat 35 soal yang baik dari 50 soal $(70 \%)$.

5. Fungsi Pengecoh soal Penilaian Akhir Semester (PAS) Gasal mata pelajaran Ilmu Pengetahuan Sosial MTs Darul Muna Ponorogo tahun pelajaran 2019/2020 termasuk pada soal yang berkualitas cukup baik. Karena dilihat dari hasil analisis terdapat separuh lebih soal pada masing-masing kelas memiliki fungsi pengecoh yang baik (baik dan cukup) yaitu pada soal kelas VII terdapat 42 soal yang berpengecoh baik dari 50 soal (84\%), pada soal kelas VIII terdapat 43 soal yang berpengecoh baik dari 50 soal $(86 \%)$, pada soal kelas IX terdapat 34 soal yang berpengecoh baik dari 50 soal (68\%).

Penelitian ini ditujukan sebagai Hasil dari penelitian ini diharapkan dapat menjadi bahan acuan guru khususnya pada evaluasi kegiatan belajar mengajar, lebih khusus lagi pada pengembilan penilaian terhadap peserta didik, agar tidak terjadi kesalahan analisis, atau pada penseleksian kualitas butir soal sehingga memungkinkan untuk memiliki bank soal yang dimaksudkan sekaligus dapat membantu dalam analisis kualitas soal untuk selanjutnya di evaluasi atau disempurnakan dan pembuka wacana peneliti mengenai hal-hal yang baru serta dapat bermanfaat untuk menambah pengetahuan dan keterampilan dalam 
Analisis Butir Soal Penilaian Akhir Semester Gasal Mata Pelajaran Ilmu Pengetahuan Sosial MTs

Darul Muna Ponorogo Tahun Pelajaran 2019/2020

penerapan analisis butir soal mata pelajaran Ilmu Pengetahuan Sosial, termasuk didalamnya mengembangkan penelitian ini agar lebih efektif dan efisien.

\section{DAFTAR PUSTAKA}

Amalia, Ata Nayla dan Widayati, Ani. "Analisis Butir Soal Tes Kendali Mutu Kelas XII SMA Mata Pelajaran Ekonomi Akuntansi Di Kota Yogyakarta Tahun 2012," Jurnal Pendidikan Akuntansi Indonesia, 1, 2012.

Arikunto, Suharsimi. Dasar-dasar Evaluasi Pendidikan Jakarta: Bumi Aksara, 2013.

Depdiknas, Panduan Analisis Butir Soal Jakarta: Dirjen Menajemen Pendidikan Dasar dan Menengah, 2008.

Hudaa, Nuril dan Wahyuni, Tutik Sri. "Analisis Butir Soal IPA Try Out USBN Tahun Ajaran 2018/2019 dalam Kaitannya dengan Level Kognitif," Jurnal Pendidikan dan Pembelajaran Dasar Madrasah, 01. Desember 2019.

Nugrahanti, Aditya Melia. “Analisis Butir Soal Ujian Akhir Semester Gasal Mata Pelajaran Akuntansi Keuangan Kelas XI Kompetensi Keahlian Akuntansi SMK Negeri 1 Yogyakarta tahun ajaran 2012/2013," Skripsi, FE UNY, Yogyakarta, 2013.

Oktanin, Wika Sevi. Analisis Butir Soal Ujian Akhir Semester Genap Mata Pelajaran Ekonomi Akuntansi Kelas XI IPS SMA N 1 Kalasan Tahun Ajaran 2013/2014. Yogyakarta: Skripsi Jurusan Pendidikan Akuntansi, Fakultas Ekonomi, Universitas Negeri Yogyakarta, 2015.

Rusmawan, Putu Ngurah. "Analisis Butir Soal Ujian Akhir Semester Mata Pelajaran Bahasa Inggris Kelas VII SMPN 2 Tegalsiwalan," Jurnal Linguista, 01, 2018.

Widyarini, Shinta. Analisis Kualitas Butir Soal Ujian Akhir Semester Gasal Mata Pelajaran Ekonomi Akuntansi Kelas Xii IPS SMA $N 1$ Kalasan Tahun 2014/2015. Yogyakarta: Skripsi Program Studi Pendidikan Akuntansi, Jurusan Pendidikan Akuntansi, Fakultas Ekonomi, Universitas Negeri Yogyakarta, 2015. 